\title{
Effect of Copper and Iron on Acidogenic Biomass in an Anaerobic Packed Bed Reactor
}

\author{
Gonzalo M. Figueroa-Torres ${ }^{1}$, Maria T. Certucha-Barragán ${ }^{1 *}$, \\ Francisco J. Almendariz-Tapia ${ }^{1}$, Onofre Monge-Amaya ${ }^{1}$, Evelia Acedo-Félix ${ }^{2}$, \\ Martín I. Pech-Canul ${ }^{3}$, Ana L. Leal-Cruz ${ }^{4}$, Carlos I. VillaVelázquez-Mendoza ${ }^{5}$ \\ ${ }^{1}$ Department of Chemical Engineering and Metallurgy, Universidad de Sonora, Hermosillo, Mexico \\ ${ }^{2}$ Centro de Investigación y de Estudios Avanzados, CINVESTAV, Saltillo, México \\ ${ }^{3}$ Centro de Investigación en Alimentación y Desarrollo, CIAD, Hermosillo, México \\ ${ }^{4}$ Departamento de Investigación en Polímeros y Materiales, Universidad de Sonora, Hermosillo, México \\ ${ }^{5}$ Facultad de Ingeniería Civil, Universidad de Colima, Colima, México \\ Email: ${ }^{\text {mtcertucha@iq.uson.mx }}$
}

Received 17 February 2014; revised 3 May 2014; accepted 16 May 2014

Copyright (C) 2014 by authors and Scientific Research Publishing Inc.

This work is licensed under the Creative Commons Attribution International License (CC BY).

http://creativecommons.org/licenses/by/4.0/

(c) (i) Open Access

\section{Abstract}

The aim of this study was to evaluate the effect of copper and iron on acidogenic biomass immobilized on clinoptilolite in an anaerobic packed bed reactor. Copper and iron were fed to the reactor at concentrations of 100 and $300 \mathrm{mg} \cdot \mathrm{L}^{-1}$, respectively. Both metal ions had insignificant inhibitory effect over the metabolism of the biomass, specifically, on substrate consumption and production of volatile fatty acids (VFAs). The microstructural characterization of the biofilm by Scanning Electron Microscopy showed no effect on the morphology of the microorganisms after the metals treatment. Copper and iron removal was also measured in the reactor, achieving a breakthrough time of 3 days, during which removal efficiencies were higher than $90 \%$. It was also observed that the biomass had a greater affinity for copper. The results indicate that acidogenic biomass can be used effectively as a sorbent agent. The pollution of river-streams with heavy metals-mainly copper and iron-was one of the most compelling motivations for conducting this investigation. The San Pedro River Basin, a trans-boundary river that originates near the mining town of Cananea, Sonora, México, and flows to Arizona, USA, exemplifies this environmental issue.

\section{Keywords}

Acidogenesis, Anaerobic Digestion, Biomass, Copper, Iron, Clinoptilolite

\footnotetext{
*Corresponding author.

How to cite this paper: Figueroa-Torres, G.M., Certucha-Barragán, M.T., Almendariz-Tapia, F.J., Monge-Amaya, O., Acedo-Félix, E., Pech-Canul, M.I., Leal-Cruz, A.L. and VillaVelázquez-Mendoza, C.I. (2014) Effect of Copper and Iron on Acidogenic Biomass in an Anaerobic Packed Bed Reactor. Advances in Bioscience and Biotechnology, 5, 564-571. 


\section{Introduction}

Mining industry is one of the most important economic activities in Mexico, particularly in the state of Sonora, where the main metals recovered are: copper, silver, and gold. Metallurgical processes associated with the production of these valuable products involve extraction and purification processes that result in the disposal of heavy metals into the environment, creating a significant problem of public health [1] [2]. An example of this kind of pollution problems is the San Pedro River Basin, which is a trans-boundary river that originates near the mining town of Cananea, Sonora, México, and flows to Arizona, US, where it joins the Gila River. The river stream has been polluted due to its proximity to the acid mine drainage (AMD) generated by the mining industries of this region. Particularly in this river, two metals (copper and iron) are found at higher concentrations than those established in the Mexican norm (NOM-001-ECOL-1996, NOM-002-ECOL-1996 and NOM-003ECOL-1996) for water quality [3] [4].

Copper and iron are heavy metals found within the cell structure, since they participate in a great number of enzymatic systems. However, due to their non-biodegradable nature, these heavy metals can be accumulated in the environment at toxic concentrations for living organisms [5]. Mining effluents generally end up mixing with natural and urban streams that contain high organic load and are treated by anaerobic digestion. This technology uses anaerobic microorganisms to remove organic compounds, but the presence of heavy metals in wastewaters causes an inhibition in the metabolism of the biomass [6].

The two main groups of microorganisms found in anaerobic digestion are acidogenic and methanogenic bacteria. Acidogenic bacteria degrade organic matter into volatile fatty acids (VFAs), while methanogenic bacteria convert VFAs into carbon dioxide and methane. Methanogenic biomass is generally more sensible to changes in their growing conditions because their environmental requirements, such as temperature, $\mathrm{pH}$, and presence of toxic compounds, are stricter than the requirements of acidogenic biomass [7] [8]. Thus, acidogenic biomass can be used for the treatment of heavy-metal containing wastewaters eliminating the inhibition of microorganisms growth caused by the acid $\mathrm{pH}$ of mining effluents.

However, there are certain problems that affect the process efficiency during the operation of anaerobic bioreactors, such as: 1) biomass washout, 2) liquid-solid separation difficulties, and 3) pressure drops. These problems originate because microbial biomass generally consists of small cells with low density and mechanical strength. The immobilization of biomass in a suitable matrix can overcome these problems by improving the growth of microorganisms as a biofilm. The packed bed reactor is the most commonly used reactor in which bacteria colonize a solid surface, as support medium. Among the wide variety of materials used as support, zeolites are a group of crystalline minerals that have been successfully employed as support medium. Due to their structural and physical properties, such as: channel and pore cavities, minimum diameter of pores in the range of 3 to $10 \AA$, average surface area of $24.9 \mathrm{~m}^{2} / \mathrm{g}$, low bulk density, high exchange (CEC) and adsorption capacities, zeolites are ideal for biological wastewater processes [9].

Thus, the aim of this study was to evaluate the effect of copper and iron on acidogenic biomass immobilized on clinoptilolite in an anaerobic packed bed reactor.

\section{Materials and Methods}

The studies were performed in an acrylic reactor of $1.9 \mathrm{~L}$ working volume, $50 \mathrm{~cm}$ height and $7 \mathrm{~cm}$ diameter, as shown in Figure 1. The reactor was packed with $1.05 \mathrm{~kg}$ of clinoptilolite with a particle size within the range of $4-4.75 \mathrm{~mm}$, and it was inoculated with $300 \mathrm{~mL}$ of anaerobic sludge. The reactor was placed in a room with controlled temperature of $30^{\circ} \mathrm{C}$, and the volumetric flow, Q, was set at $1.9 \mathrm{~L} / \mathrm{d}$ to achieve a hydraulic residence time (HRT) of $1 \mathrm{~d}$.

Prior to the addition of metals, the reactor was operated for 120 days to achieve acidogenic conditions. The effluent stream was recirculated at a rate of $20 \mathrm{~mL} \cdot \mathrm{min}^{-1}$ during the first 50 days to favor the growth of microorganisms and was completely removed thereafter. The feed medium was prepared as follows $\left(\mathrm{mg} \cdot \mathrm{L}^{-1}\right): 1044$ $\mathrm{NH}_{4} \mathrm{Cl}, 270 \mathrm{KCl}, 169 \mathrm{~K}_{2} \mathrm{HPO}_{4}, 150 \mathrm{MgCl}_{2} \cdot 6 \mathrm{H}_{2} \mathrm{O}, 50 \mathrm{CaCl}_{2} \cdot 2 \mathrm{H}_{2} \mathrm{O}, 18$ yeast extract, and $1 \mathrm{~mL} \cdot \mathrm{L}^{-1}$ of trace elements. The $\mathrm{pH}$ was adjusted to 4 to inhibit the growth of methanogenic bacteria and to resemble the pH levels of mining effluents. Organic matter consisted of dextrose (substrate), and the concentration was gradually increased from 2 to $5 \mathrm{~g} \cdot \mathrm{L}^{-1}$ to enhance the production of VFAs.

Liquid samples were taken from the reactor on a daily basis at the inlet and outlet points and were analyzed to determine: chemical oxygen demand (COD), dextrose concentration and production of VFAs. COD was measured 


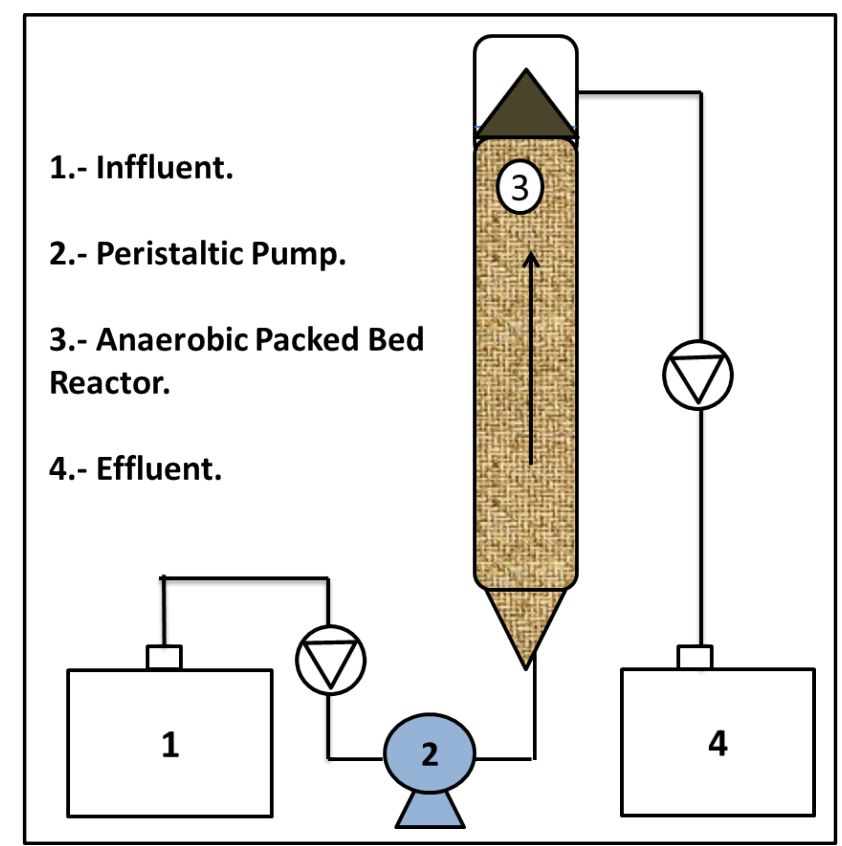

Figure 1. Anaerobic packed bed reactor with acidogenic biomass immobilized in clinoptilolite.

according to the procedures established on the APHA standard methods [10], dextrose concentration analysis was carried out according to the DNS method (3,5-dinitrosalicylic acid) [7] [11], and total VFAs (expressed in eq $\cdot \mathrm{L}^{-1}$ of acetate) were determined by the titration method proposed by Powell and Archer [12]. To observe the effect of copper and iron on the biomass, addition of both metals started at day 120, when measurements yielded constant acidogenic values. During the exposure stage (days 120 - 145), copper and iron were constantly fed to the reactor by adding standard solutions of copper sulfate $\left(\mathrm{CuSO}_{4}\right)$ and ferrous sulfate $\left(\mathrm{Fe}_{2} \mathrm{SO}_{4} \cdot 7 \mathrm{H}_{2} \mathrm{O}\right)$ to the feed medium so as to obtain concentrations of $100 \mathrm{mg} \cdot \mathrm{L}^{-1}$ of $\mathrm{Cu}(\mathrm{II})$ and $300 \mathrm{mg} \cdot \mathrm{L}^{-1}$ of $\mathrm{Fe}(\mathrm{II})$. It should be noted that the results presented in this work include only days 95 - 145 of the experiment.

Breakthrough curves $\left(C / C_{o}\right.$ vs $\left.t\right)$ were determined for both metals and the maximum uptake capacity of the reactor, $C_{\max }$, was calculated according to Equation (1) [13]:

$$
C_{\max }=Q \int_{0}^{t} C_{a d s} \mathrm{~d} t
$$

where $C_{a d s}$ is the metal retained by the reactor $\left(C_{o}-C\right)$ at a given time, $t$, and $Q$ is the volumetric flow of the feed medium. The total amount of metals load to the reactor was calculated to determine the sorption yield, which represents the percentage of metals sequestered in relation to the feed load. Metal concentration was measured using an atomic absorption spectrometer AAnalyst 400 (Perkin Elmer). Samples were diluted in 2\% nitric acid $\left(\mathrm{HNO}_{3}\right)$.

Before and after exposure of copper and iron, clinoptilolite samples were removed from the reactor for their microstructural characterization by SEM. The characterization was carried out in environmental conditions, at an acceleration voltage of $30 \mathrm{keV}$, in a Philips SEM equipment provided with a Falcon ${ }^{\mathrm{TM}}$ EDS device. Prior to the SEM analysis, zeolite with immobilized biomass were fixed by immersion in glutaraldehyde $5 \%(\mathrm{v} / \mathrm{v})$ at $4{ }^{\circ} \mathrm{C}$ for $24 \mathrm{~h}$, followed by a post-fixation in osmium tetroxide solution $1 \%(\mathrm{w} / \mathrm{v})$ at $4^{\circ} \mathrm{C}$ for $2 \mathrm{~h}$. The samples were dehydrated using a series of acetone solutions (30\%, 40\%, 50\%, 70\%, 80\%, 90\% and $100 \%)$.

\section{Results and Discussion}

Figure 2 shows the results obtained by the COD measurements in the acidogenic reactor. Days 95 - 120 correspond to the COD concentration levels before the reactor was fed with copper and iron. COD removal values were close to $20 \%$ before biosorption. From day 120 onwards, COD concentration levels remained practically the same. A slight decrease can be observed in the last 10 days of the experiment, during which COD removals 
were close to $10 \%$. Methanogenic bacteria generally achieve high COD removals when used in continuous systems. High COD removals indicate that complex organic matter is degraded and converted by bacteria to methane and $\mathrm{CO}_{2}$, the final products of anaerobic digestion. Acidogenic bacteria, however, degrade substrates only until the production of VFAs, which are also organic matter and hence COD removals are low. Overall, the low COD removals found in this study, confirm that the biomass is only performing the first step of digestion, acidogenesis.

The level of acidogenesis can be determined by measuring the consumption of the substrate used by the microorganisms [7]. Figure 3 shows the dextrose consumption in the reactor. Dextrose was fed to the reactor at a constant concentration of $5 \mathrm{~g} \cdot \mathrm{L}^{-1}$ during days 95 - 145. It can be seen that, before copper and iron were fed, average dextrose concentration at the outlet point was below $1 \mathrm{~g} \cdot \mathrm{L}^{-1}$. Since dextrose removals were above $90 \%$, it can be concluded that the biomass was metabolically active. Once the biosorption stage started, the dextrose consumption began to decrease to levels between $85 \%$ and $80 \%$, until it finally reached levels near $70 \%$ during the last days. This indicates that the addition of copper and iron caused a low inhibition over substrate consumption. Some metals are part of essential enzymes responsible of numerous anaerobic reactions. However, since heavy metals are not biodegradable, they can accumulate to toxic concentrations that inhibit the cellular metabolism. This toxic effect is attributed to the inhibition of the enzymatic functions and the rupture of cellular proteins within the cell [6].

The effect of copper and iron over the production of total VFAs in the reactor is shown in Figure 4. During days $95-120$, the average concentration of VFAs was $0.012 \mathrm{eq} \cdot \mathrm{L}^{-1}$. This value significantly decreased from 0.008 to $0.004 \mathrm{eq} \cdot \mathrm{L}^{-1}$ during the first 3 days in which metals were added. This shows that copper and iron inhibited the biomass, since the production of VFAs dropped almost 70\%. A slight increase in VFAs concentration can be seen from days 135 - 145, which might indicate that the biomass was beginning to adapt to the presence of both metals. The effect of heavy metals on the degradation and production of VFAs has been widely studied by Lin et al. [8] [14] [15]. The metals analyzed in these past studies were $\mathrm{Cu}, \mathrm{Cr}, \mathrm{Zn}, \mathrm{Cd}, \mathrm{Ni}$, and $\mathrm{Pb}$, and resulted in copper being the most toxic metal. The copper concentration at which VFAs production dropped by $50 \%$ was $282 \mathrm{mg} \cdot \mathrm{L}^{-1}$, whereas for methanogenic biomass the copper concentration at which production dropped by $50 \%$ was $31 \mathrm{mg} \cdot \mathrm{L}^{-1}$. It is worth mentioning that in the works of Lin et al., the tests were carried out in batch systems (metals are not fed continuously), but the results show the inhibitory effect exerted by heavy metals and reinforce the general idea that acidogens are more resistant than methanogens.

The observation of the colonized support by SEM is shown in Figure 5. Figure 5(a) and Figure 5(b) correspond to the samples before metal addition, whereas Figure 5(c) and Figure 5(d) correspond to samples taken from the reactor after the metals exposure. In Figure 5(a) and Figure 5(b) it is possible to see the development of microorganisms in the form of a biofilm and extrapollymeric substances (EPS) that cover the surface of the clinoptilolite. It can also be observed that the biofilm is composed mainly of microorganisms with bacillary

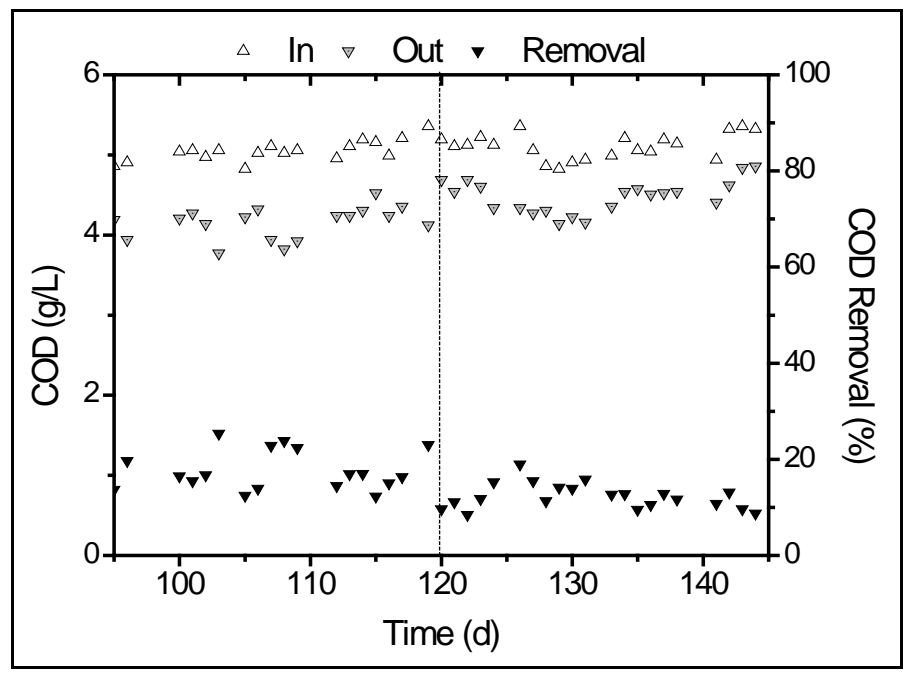

Figure 2. Concentration of COD in the acidogenic reactor before and during $\mathrm{Cu}(\mathrm{II})$ and $\mathrm{Fe}(\mathrm{II})$ exposure. 


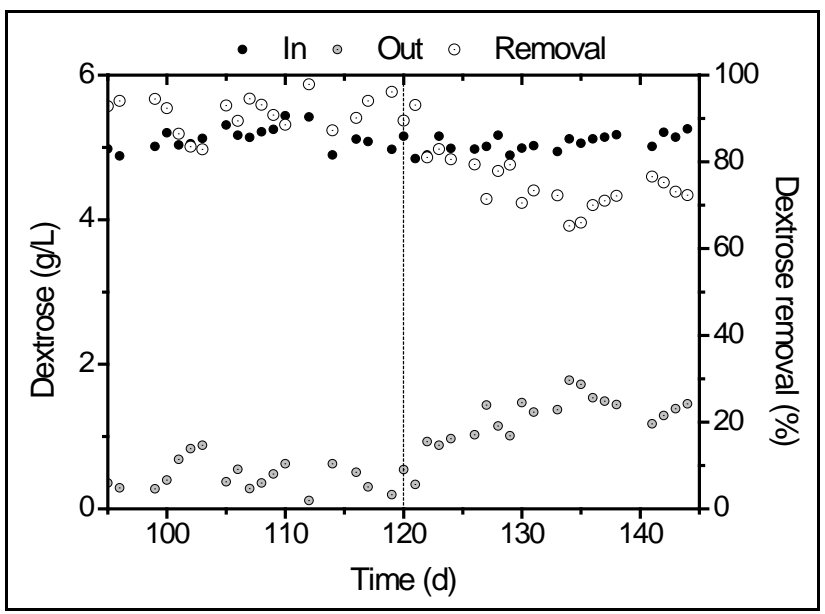

Figure 3. Dextrose consumption in the acidogenic reactor before and during $\mathrm{Cu}(\mathrm{II})$ and $\mathrm{Fe}(\mathrm{II})$ exposure.

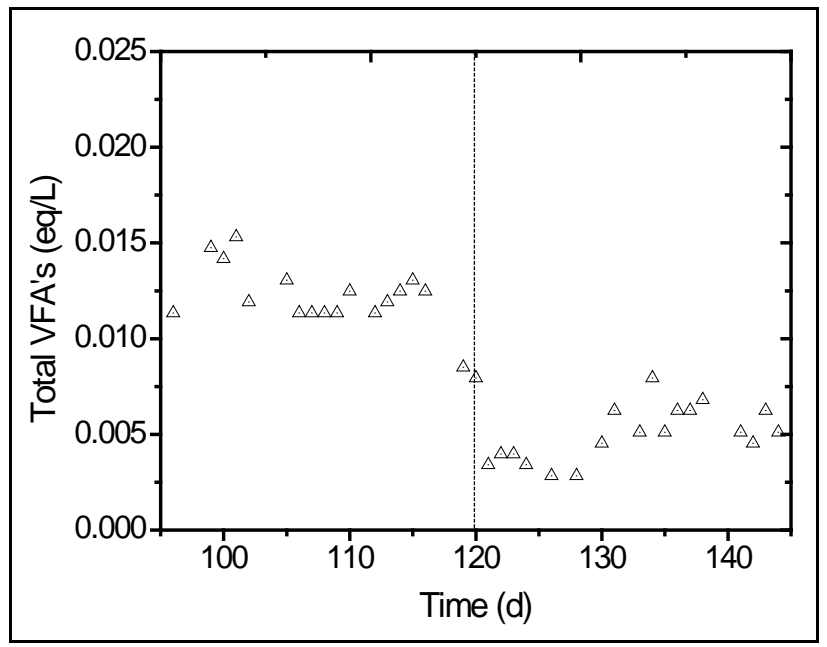

Figure 4. VFAs production in the acidogenic reactor before and during $\mathrm{Cu}(\mathrm{II})$ and $\mathrm{Fe}(\mathrm{II})$ exposure.

forms. Some of the most common genres of anaerobic microorganisms associated with acidogenic groups are Lactobacillus, Selenomomas, Sarcinas and Zymomonas [16].

The EPS are biopolymers produced during the growth of microorganisms outside of the cell wall and are constitued by a variety of high molecular weight molecules such as proteins, nucleic acids, phospholipids and polysaccharides as main components. EPS play a very important part in the formation of cell adhesion and biofilm development, but they are also involved in the binding of heavy metals. This binding process occurs due to electrostatic interactions between the negatively charged functional groups in EPS like carboxylic acids and the positively charged metallic ions [17]. These observations confirm that clinoptilolite can be used effectively as support material for the immobilization of biomass.

It can be appreciated that metal addition to the system did not affect the morphology of the microorganisms. It has been widely stated that heavy metals can be removed by biomass through biosorption, defined as the ability of some microorganisms to act as sorbent agents through physicochemical binding. This passive transport is different from bioaccumulation, in which metallic ions are metabolically transported into living cells [18] [19]. Heavy metals particulates can be observed in the SEM images of Figure 5(c) and Figure 5(d), which indicates that metals were sequestered within and outside the cell and that $\mathrm{Cu}(\mathrm{II})$ and $\mathrm{Fe}(\mathrm{II})$ removal can be carried out in this type of bioreactor using acidogenic biomass as a biosorbent.

The breakthrough curves of copper and iron can be seen in Figure 6. It is worth mentioning that the curves 


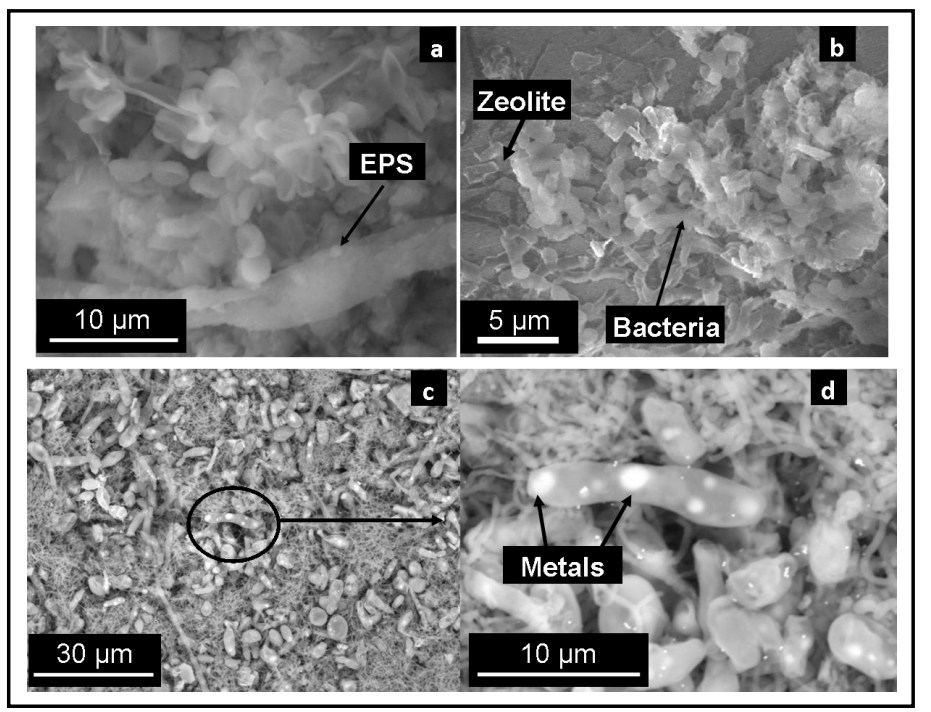

Figure 5. SEM images of colonized clinoptilolite particles before and after $\mathrm{Cu}(\mathrm{II})$ and $\mathrm{Fe}(\mathrm{II})$ exposure.

start at day 120, which is the point in which the metals were loaded to the reactor. Both metals were pumped at constant flow of $1.9 \mathrm{~L} \cdot \mathrm{d}^{-1}$. Copper and iron concentrations were 100 and $300 \mathrm{mg} \cdot \mathrm{L}^{-1}$, respectively. The breakthrough time, $t_{b}$, is defined as the time in which the outlet metal concentration reaches a maximum permissible discharge limit. Generally, this maximum level is considered to be less than $10 \%$ the inlet concentration $\left(C / C_{o}=\right.$ 0.1 ). It can be seen from Figure 6 that the breakthrough time for both metals is $t_{b}=3$ days, during which removal efficiencies were higher than $90 \%$.

Considering that the amount of iron fed to the reactor was three times greater than that of copper, it was expected that the binding sites of the biomass were predominantly saturated by iron, thus blocking the sites available for biosorption. Nevertheless, the breakthrough curves of both metals exhibit a similar behavior, leading to the conclusion that the biomass has a greater affinity towards copper. Table 1 shows that the overall biosorption yield, was slightly greater for copper than for iron, which corroborates the affinity of the biomass towards this metallic ion. Pakshirajan et al. [13] reported a copper sorption yield of 57\% (during the first out of two biosorption cycles) using a column that was inoculated with the fungus $P$. chrysosporium and packed with polyurethane foam cubes $(1 \times 1 \times 1 \mathrm{~cm})$. This result is similar to the $53 \%$ yield for copper found in this study. In order for a material to be considered as a good biosorbent, it is generally desirable that it offers a delayed breakthrough time, a high uptake capacity and a steep breakthrough curve; these parameters allow the easy evaluation of the process efficiency. However, external factors such as the inlet metal concentration, volumetric flow and the amount of biosorbent used in the column also have an influence over the parameters previously described [20].

\section{Conclusion}

The heavy metals studied-Cu(II) and Fe(II), showed no real effect on the COD removals of the biomass or the substrate consumption, which was slightly affected throughout the experiment. On the other hand, VFAs concentrations decreased when the metals were added to the bioreactor, but concentration values began to increase from day 135 onwards. The use of non-viable biomass can overcome inhibitory effects, since the toxicity would be negligible. However, the use of living biomass offers an advantage in that organic matter can also be treated in the reactor, favoring the production of by-products which may be reutilized. For instance, VFAs produced by acidogenic bacteria can be used as substrate for methanogenic bacteria, creating a sustainable process. From SEM analysis, it is observed that clinoptilolite can be used effectively as support material for biomass immobilization. Besides, it was possible to observe that there was no discernible change in the morphology of microorganisms after $\mathrm{Cu}(\mathrm{II})$ and $\mathrm{Fe}(\mathrm{II})$ exposure, and that both metals were sequestered within and outside the cell. The acidogenic reactor achieved an overall sorption of yield of 51\%. These results indicate that the type of biomass used in this study could be implemented as a secondary treatment of mining effluents to remove copper and iron from industrial wastewaters. 


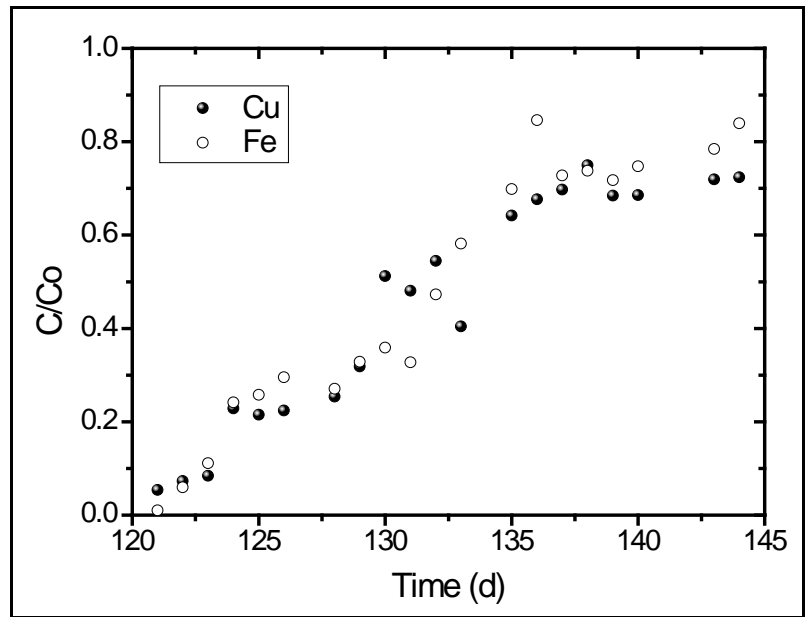

Figure 6. Breakthrough curves of $\mathrm{Cu}(\mathrm{II})$ and $\mathrm{Fe}(\mathrm{II})$ in the acidogenic reactor.

Table 1. Sorption parameters of $\mathrm{Cu}(\mathrm{II})$ and $\mathrm{Fe}(\mathrm{II})$ in the acidogenic reactor during metal exposure.

\begin{tabular}{cccc}
\hline Metal & $\boldsymbol{C}_{\max }(\mathbf{m g})$ & Metal loading $(\mathbf{m g})$ & Sorption yield (\%) \\
\hline $\mathbf{C u}(\mathrm{II})$ & 2461.68 & 4601.61 & 53 \\
$\mathbf{F e}(\mathrm{II})$ & 6803.06 & 13486.2 & 50 \\
Overall & 9264.75 & 18087.81 & 51 \\
\hline
\end{tabular}

\section{Acknowledgements}

The authors would like to thank: the National Council of Science and Technology (CONACyT) for their support in awarding a scholarship for the project, and the Department of Chemical Engineering and Metallurgy of the University of Sonora for the space and equipment facilitated during the realization of this work.

\section{References}

[1] Cañizares-Villanueva, R.O. (2000) Biosorción de metales pesados mediante el uso de biomasa microbiana. Revista Latinoamericana de Microbiología, 42, 131-143.

[2] Monge-Amaya, O., Valenzuela-Garcia, J.L., Acedo-Felix, E., Certucha-Barragan, M.T. and Almendariz-Tapia, F.J. (2008) Copper Biosorption in Batch and Continuous Evaluation Using Immobilized Aerobic Bacteria in Clinoptilolite. Revista Internacional De Contaminacion Ambiental, 24, 107-115.

[3] Gómez-Alvarez, A., Villalba-Atondo, A., Acosta-Ruiz, G., Castañeda-Olivares, M. and Kamp, D. (2004) Metales pesados en el agua superficial del río San Pedro durante 1997-1999. Revista Internacional de Contaminación Ambiental, 20, 1-8.

[4] Gomez-Alvarez, A., Meza-Figueroa, D., Villalba-Atondo, A.I., Valenzuela-Garcia, J.L., Ramirez-Hernandez, J. and Almendariz-Tapia, F.J. (2009) Estimation of Potential Pollution from Mine Tailings in the San Pedro River (19932005), Mexico-US Border. Environmental Geology, 57, 1469-1479. http://dx.doi.org/10.1007/s00254-008-1424-8

[5] Nies, D.H. (1999) Microbial Heavy-Metal Resistance. Applied Microbiology and Biotechnology, 51, 730-750. http://dx.doi.org/10.1007/s002530051457

[6] Chen, Y., Cheng, J.J. and Creamer, K.S. (2008) Inhibition of Anaerobic Digestion Process: A Review. Bioresource Technology, 99, 4044-4064. http://dx.doi.org/10.1016/j.biortech.2007.01.057

[7] García-Morales, J., Romero-García L. and Sales-Márquez, D. (1999) Influencia de las paradas estacionales sobre la biomasa inmovilizada en reactores anaerobios. Ingeniería del Agua, 6, 249-256.

[8] Lin, C.Y. and Chen, C.C. (1999) Effect of Heavy Metals on the Methanogenic UASB Granule. Water Research, 33, 409-416. http://dx.doi.org/10.1016/S0043-1354(98)00211-5

[9] Montalvo, S., Guerrero, L., Borja, R., Sanchez, E., Milan, Z., Cortes, I. and de la Rubia, M.A. (2012) Application of 
Natural Zeolites in Anaerobic Digestion Processes: A Review. Applied Clay Science, 58, 125-133. http://dx.doi.org/10.1016/j.clay.2012.01.013

[10] APHA (1995) Standard Methods. American Public Health Association, Washington DC.

[11] Miller, G. (1959) Use of Dinitrosalicylic Acid Reagent for Determination of Reducing Sugar. Analytical Chemistry, 31, 426-428. http://dx.doi.org/10.1021/ac60147a030

[12] Powell, G.E. and Archer, D.B. (1989) Online Titration Method for Monitoring Buffer Capacity and Total Volatile Fatty Acid Levels in Anaerobic Digesters. Biotechnology and Bioengineering, 33, 570-577. http://dx.doi.org/10.1002/bit.260330509

[13] Pakshirajan, K. and Swaminathan, T. (2009) Biosorption of Copper and Cadmium in Packed Bed Columns with Live Immobilized Fungal Biomass of Phanerochaete chrysosporium. Applied Biochemistry and Biotechnology, 157, 159173. http://dx.doi.org/10.1007/s12010-008-8283-3

[14] Lin, C.Y. (1993) Effect of Heavy Metals on Acidogenesis in Anaerobic Digestion. Water Research, 27, 147-152. http://dx.doi.org/10.1016/0043-1354(93)90205-V

[15] Lin, C.Y. and Chen, C.C. (1997) Toxicity-Resistance of Sludge Biogranules to Heavy Metals. Biotechnology Letters, 19, 557-560. http://dx.doi.org/10.1023/A:1018345622030

[16] Almendariz-Tapia, F.J. (2001) Degradación del alquilbencen sulfonato lineal (LAS) en un reactor acidogénico bioaumentado con una cepa de Pseudomonas aeruginosa M113. Universidad Autónoma Metropolitana, Iztapalapa.

[17] Pal, A. and Paul, A.K. (2008) Microbial Extracellular Polymeric Substances: Central Elements in Heavy Metal Bioremediation. Indian Journal of Microbiology, 48, 49-64. http://dx.doi.org/10.1007/s12088-008-0006-5

[18] Chojnacka, K. (2010) Biosorption and Bioaccumulation-The Prospects for Practical Applications. Environment International, 36, 299-307. http://dx.doi.org/10.1016/j.envint.2009.12.001

[19] Volesky, B. (2003) Sorption and Biosorption. BV Sorbex, Inc., Montreal, 316.

[20] Park, D., Yun, Y.S. and Park, J.M. (2010) The Past, Present, and Future Trends of Biosorption. Biotechnology and Bioprocess Engineering, 15, 86-102. 